\title{
NEKA PITANJA DRŽAVLJANSTVA U SPORTU KAO FENOMEN MEĐUNARODNOG SPORTSKOG PRAVA
}

\author{
UDK: 341.9 \\ Primljeno: 15. 10. 2016. \\ Pregledni rad
}

I u grupnim i u individualnim sportovima, proces olakšane naturalizacije sportaša uzima sve više maha. Budući da sportaši moraju posjedovati državljanstvo određene države da bi je mogli predstavljati na međunarodnim natjecanjima, mnoge države pribjegavaju ovoj praksi te nude posebne vrste viza ili olakšani postupak naturalizacije za „obećavajuće“ sportaše. Ista je situacija vezana i uz nastupanje na Olimpijskim igrama. Najčešće se radi o stranim sportašima koji su članovi nacionalnih sportskih timova država čiji su državljani, a od kojih se očekuje da bi mogli nastupati za nacionalni tim države u koju dolaze kao sportaši stranci. I dok jedni u ovakvom razvoju događaja ne vide ništa loše, drugi pozivaju na ozbiljno promišljanje o ,utjecaju pojačane mobilnosti sportaša na pretpostavljenu vezu između odanosti, identiteta i državljanstva“. Stoga autorica u ovom tekstu pokušava odgovoriti na sljedeća pitanja: U kojoj mjeri globalizacija i transnacionalizacija sporta mijenjaju našu percepciju državljanstva i pripadanja? Je li postojeći koncept državljanstva adekvatan i u sportskom kontekstu? Treba li intervenirati u odnos državljanstva i sporta?

\section{Ključne riječi: državljanstvo, sport, naturalizacija, nastupanje za državnu reprezentaciju, diskriminacija}

\section{UVOD}

Nekoć je bilo lako utvrditi tko za koga navija. Smatralo se da sport mora imati identitet, podrazumijevajući pod tim identitet navijačke baze. Prodorom globalizacije i krupnog kapitala u međunarodne sportske organizacije i institucije Europske unije, lokalni identitet izgubio se i kod državnih reprezentacija. Kako je, riječima Georgea Orwella, nogomet jedini sport koji u periodu od 90 minuta uspijeva zadržati fokus cijele populacije na pripadnosti nacionalnoj grupaciji, a ujedno je i najpopularniji sport diljem svijeta, možda upravo nogomet pruža najbolji uvid u različite procese globalizacije. Tako su na posljednjem EURO-u (2016.) u 24 državne reprezentacije igrali igrači iz 36 različitih nacionalnih liga i 38 različitih članica FIFA-e, s obzirom na to da je za američku državnu reprezentaciju igrao i jedan igrač iz kanadskog tima te da je Velika Britanija (uobičajeno) zastupljena s više od jedne državne reprezentacije. Najveći broj državnih reprezentacija danas predstavlja kombinaciju „domaćih domaćih“, „domaćih imigranata“ te „stranih imigranata“, i po tome sve 
Dr. sc. Ines Medić: Neka pitanja državljanstva u sportu kao fenomen međunarodnog sportskog prava Zbornik radova Pravnog fakulteta u Splitu, god. 54, 2/2017., str. 415.- 435.

više nalikuju na svoju širu populaciju. ${ }^{1}$ Međutim, dok velike europske lige i njihovi glavni klubovi nedvojbeno profitiraju od priljeva stranih igrača, to nije uvijek slučaj i s državnom reprezentacijom. ${ }^{2}$

Unatoč tome, i u grupnim i u individualnim sportovima, proces olakšane naturalizacije ${ }^{3}$ sportaša uzima sve više maha. Mnoge države pribjegavaju ovoj praksi te nude posebne vrste viza ili olakšani postupak naturalizacije za „obećavajuće“ sportaše. I sa aspekta sportaša i sa aspekta države o kojoj je riječ, ovakav razvoj događaja zapravo predstavlja ,win-win" situaciju. Država dobiva priliku za slavu, a sportašima se omogućuje sudjelovanje na velikim natjecanjima na kojima inače ne bi mogli sudjelovati zbog jake konkurencije u vlastitoj državi, stoga se koriste svim raspoloživim sredstvima da do toga i dođu.

Ista je situacija vezana i uz nastupanje na Olimpijskim igrama. Iako Olimpijska povelja zahtijeva da svi sportaši budu državljani države za koju se natječu, fenomen „zamjene putovnice“ (passport swapping), kako ga često nazivaju, prilično je uobičajen. ${ }^{4}$ Štoviše, već su se iskristalizirale i najčešće tehnike, isprobane i testirane na dosadašnjim Olimpijskim igrama. Tako se navode sljedeće taktike: ${ }^{5}$ iskoristi svoje bogatstvo i tatinu putovnicu, ${ }^{6}$ prodaj svoje talente kao sportaš-plaćenik, ${ }^{7}$

1 Mudde, C.: Football and Globalization: the EURO 2016 in Numbers, str. 1. Preuzeto sa http:// www.huffingtonpost.com/cas-mudde/football-and-globalizatio_b_10424170.html, 19. X. 2016.

2 Kao što je to razvidno u slučaju Engleske, koja još od 1966. godine nije imala većeg uspjeha. Slična je i situacija s državnom reprezentacijom Katara koja, unatoč izdašnom investiranju u naturalizirane strane talente, još uvijek nije postigla očekivane rezultate. Stoga su sve glasniji zahtjevi da se smanji broj stranih igrača u reprezentaciji u korist „domaćih“ (home grown players). Imajući u vidu da je upravo Katar domaćin Svjetskog prvenstva 2022., na tome se intenzivno radi, iako je, zbog ogromnog bogatstva njegovih stanovnika čak i unatoč izdašnim ugovorima, često teško animirati domaće igrače. Khatri, S. S.: „Proposal to cut foreigners from Qatar's national team sparks the debate“, Doha News, 24. XI. 2016.

3 Prirođenje ili naturalizacija jest način stjecanja državljanstva na vlastitu zamolbu osobe koja želi postati državljaninom neke države. Prva pretpostavka je, dakle, da je riječ o strancu (tj. osobi drugog državljanstva ili bez državljanstva) koji svojevoljno želi promijeniti svoj državljanski status. Druga je pretpostavka da takav stranac ispuni određene uvjete koje odnosna država predviđa za stjecanje državljanstva naturalizacijom. Uvjeti variraju od države do države, ovisno o stopi naturalizacije koju država može tolerirati. Stopa naturalizacije ovisi pak o nacionalnoj sigurnosti, povijesnim iskustvima, kohezivnosti nacije, etičkoj i religijskoj homogenosti, gospodarskom sustavu i dr. Tako: Mintas-Hodak, LJ./Mateša, Z.: „Državljanstvo športaša“, u: Crnić, I./Crnić, J./Ćurković, M./Gliha, I./Ivančić-Kačer/B./ Ivkošić, M./Kačer, H./Labar,B./Mateša, Z./Mijatović, N./Mintas-Hodak, LJ./Momčinović/H./Perkušić, A./Petrović, S./Primorac, D.: (Uvod u) Sportsko pravo, Inženjerski biro, d.d., Zagreb, 2009., str. 234.

4 Tako je na Olimpijskim igrama u Sočiju, 2014. godine, reprezentacija Velike Britanije uključivala 61 sportaša rođenog na drugom kontinentu, s time da je jedna od njih (Olga Butkevych) putovnicu Velike Britanije dobila tek nekoliko mjeseci prije samih igara.

5 Vidi: In the Olympics, the country you represent could be meaningless, preuzeto sa http://www. news herald.com/article/HR/20140206/NEWS/140209426, 19. X. 2016.

6 Tako se, svjetski poznata cross-over violinistica Vanesa Mae, Tajlanđanka, koja je preko očuha dobila i britansko državljanstvo, u Sočiju natjecala za Tajland u alpskom skijanju.

7 Jedna od država koja, izdašnim investiranjem u obećavajuće sportaše (pa i cijele timove) u velikoj mjeri potiče upravo takvo ponašanje je Katar, koji je, primjerice, 2000. godine kupio cijeli bugarski tim dizača utega (ukupno 8 sportaša), u zamjenu za državljanstvo i preko milijun dolara. 
Dr. sc. Ines Medić: Neka pitanja državljanstva u sportu kao fenomen međunarodnog sportskog prava Zbornik radova Pravnog fakulteta u Splitu, god. 54, 2/2017., str. 415.- 435.

predstavljaj državu koja je priznata na Olimpijskim igrama, ${ }^{8}$ koristi svoje kraljevske veze $^{9}$ ili se naprosto odluči za bob. ${ }^{10}$

I dok jedni u ovakvom razvoju događaja ne vide ništa loše, drugi pozivaju na ozbiljno promišljanje o ,utjecaju pojačane mobilnosti sportaša na pretpostavljenu vezu između odanosti, identiteta i državljanstva“". ${ }^{11}$ Stoga ćemo u daljnjem tekstu pokušati odgovoriti na pitanja: U kojoj mjeri globalizacija i transnacionalizacija sporta mijenjaju našu percepciju državljanstva i pripadanja? Je li postojeći koncept državljanstva adekvatan i u sportskom kontekstu? Treba li intervenirati u odnos državljanstva i sporta?

\section{OPĆENITO O DRŽAVLJANSTVU}

Na pitanje što označava pojam državljanstva, obično se odgovara: državljanstvo je veza koja spaja pojedinu osobu za određenu državu. ${ }^{12}$ Govori se o pravnoj vezi ili o pravnom odnosu između pojedinca i države. ${ }^{13}$ Dakle, državljanstvo je pravna pripadnost određenoj državi. ${ }^{14}$ Riječ je o trajnom pravnom odnosu između države

8 Sportaši iz država koje Olimpijski odbor ne priznaje mogu se natjecati jedino pod zastavom neke druge države.

9 Za neke olimpijce pozivanje na obiteljsko stablo otvara brojne mogućnosti, u smislu izbora zastave pod kojom će se natjecati. Tako je, primjerice, na Olimpijskim igrama u Sočiju, njemački princ Hubertus von Hohenlohe odlučio natjecati se u slalomu i to pod zastavom Meksika. Iako je rođen u Meksiku i baka mu je bila napola Meksikanka, on sam nije imao nikakvih ranijih kontakata s Meksikom.

10 Kao što je to napravila Lolo Jones, nakon što je ostala bez medalje u Pekingu u utrci s preponama. U bobu je imala više sreće i nakon samo godinu dana u dvojcu je osvojila drugo mjesto u svjetskom poretku.

11 Kostakopoulou, D./Schrauwen, A.: „Olympic citizenship and the (un)specialness of national vest: rethinking the links between sport and citizenship law", International Journal of Law and Context, Vol. 10, No. 2, 2014., str. 143-162. Preuzeto sa https://papers.ssrn.com/sol3/papers.cfm?abstract id $=2562810$ , 3. X. 2016., str. 36.

12 Anderson, B.: Exclusion, Failure, and the Politics of Citizenship, RCIS Working Paper, No 2014/1, January 2014., Ryerson University; Bauböck, R.: Migration and Citizenship: Legal Status, Rights and Political Participation, Amsterdam, 2006.; Cohen, J.: „Changing Paradigms of Citizenship and the Exclusiveness of the Demos", International Sociology, Vol. 14, No. 3., str. 245.-268.; Closa, C.: „Citizenship of the Union and Nationality of Member States“, Common Market Law Review, 32, 1995, str. 487.-518.; Habermas, J.: „Državljanstvo i nacionalni identitet: razmišljanja o evropskoj budućnosti““, , 11 (1/1991.), str. 141.; Hansen, R.: „The Politics of Citizenship in 1940s Britain: The British Nationality Act“, Twentieth Century Brit. Hist., Vol. 10, Issue 1, 1999., str. 67-95; te od hrvatskih Krbek, I.: „Državljanstvo“", Hrvatska enciklopedija, sv. V., Zagreb, 1945.; Borković, I.: Upravno pravo, Informator, Zagreb, 1997., str. 147; Andrassy, J./Bakotić, B./ Vukas, B.: Međunarodno pravo, I. dio, Školska knjiga Zagreb, 1995. , str. 282; Degan, V: Đ.: Međunarodno pravo, Rijeka, 2000., str. 481, Ibler, V.: Rječnik međunarodnog javnog prava, Informator, Zagreb, 1987., str. 69; Sajko, K.: Međunarodno privatno pravo, Školska knjiga, Zagreb, 2009., str. 110-128 itd. Iako se određenjem i analizom pojma državljanstvo bavio veliki broj pravnih teoretičara, integralne definicije državljanstva još uvijek nema.

13 Bosnić, P.: Hrvatsko međunarodno privatno pravo, obrazloženje i komentar zakona, knjiga I., Split, 1999., str. 61.

14 Državljanstvo danas označava članstvo u političkoj zajednici - državi i treba ga razlikovati od pojma nacionalnosti, koji označava pripadnost pojedinca određenome narodu (naciji). Nacionalnost je etnički pojam koji podrazumijeva zajednički kulturni identitet pripadnika istog naroda. Globalizacija je izazvala potrebu suvremenih nacionalnih država da postanu otvorenije prema pluralizmu i različitostima. 
i fizičke osobe na osnovi kojega pojedinac stječe određena prava (npr. politička, građanska itd.), ali i dužnosti (glasovanje, lojalnost itd.) bez obzira na to nalazi li se on na njezinu području ili ne. ${ }^{15}$ Prema Europskoj konvenciji o državljanstvu iz 1997. godine ${ }^{16}$ ono označuje pravnu vezu između neke osobe i države, a ne njezino etničko porijeklo (čl. 2. toč. a). ${ }^{17}$ Drugim riječima, ono označuje pravno svojstvo na osnovi kojega drugi propisi daju takvim osobama određena prava i obveze. ${ }^{18}$

Svaka država načelno slobodno i isključivo odlučuje o tome tko joj pripada (tzv. domaine rézervé). ${ }^{19} \mathrm{U}$ skladu s načelom suverene jednakosti država (čl. 2. st. 1. Povelje Ujedinjenih naroda), svaka od njih je pozvana da sama određuje svoje državljanstvo. Isto određuje i čl. 1. Haaške konvencije o nekim pitanjima u vezi sa sukobima prava o državljanstvu od 1930. (koja nije stupila na snagu), a isto gledište izražava i Stalni sud za međunarodnu pravdu ${ }^{20}$ u svojim savjetodavnim mišljenjima br. 4. od 7. veljače 1923. i br. 7. od 15. rujna 1923., kao i Međunarodni sud pravde u Haagu u odluci u predmetu Nottebohm od 5. travnja 1955. U toj se odluci navodi da je jedino ograničenje po međunarodnom pravu to da unutrašnje pravo ne može nametnuti svoje državljanstvo osobi koja s tim pravnim poretkom nema dovoljne veze. ${ }^{21}$

Budući da svaka država sama suvereno odlučuje o uvjetima pod kojima će nekom pojedincu priznati državljanstvo, a da države prihvaćaju različite koncepte državljanstva, moguće su situacije u kojima pojedinci ostaju u potpunosti bez državljanstva ijedne države (u kojem slučaju govorimo o apatridima odnosno apolitima), ili pak istodobno imaju dva (bipatridi) ili više državljanstava (polipatridi). S obzirom na načelo isključivosti ili primata domaćeg državljanstva, osoba koja ima dva ili više državljanstava pred tijelima vlasti jedne od država čije državljanstvo ima moći će se pozivati samo na domaće državljanstvo. ${ }^{22}$

\footnotetext{
Migracije su transformirale mnoge tradicionalno nacionalne države, tako da su one danas sastavljene od više nacija ili etničkih skupina, a ponekad i pripadnika različitih religija, rasa i jezika. Način da se spriječe nejednakosti između tih različitih etničkih i socijalnih grupacija unutar države jest izjednačavanje svih članova zajednice kroz pojam državljanstva. Tako: Mintas-Hodak/Mateša, op. cit., str. 231. i 232.

15 Borković, op. cit., str. 147.

16 Navedena Konvencija stupila je na snagu 1. III. 2000. godine, no ne i za Hrvatsku.

17 Tako: Andrassy/Bakotić/Vukas, op. cit., str. 283; Degan, op. cit., str. 481. i dalje.

18 Sajko, op. cit., str. 110. 283.

19 Sa stanovišta međunarodnog prava o tome pobliže npr. Andrassy/Bakotić/Vukas, op. cit., str.

20 Prethodnik Međunarodog suda pravde u Haagu.

21 Nottebohm case, Judgment of 6 April 1955. Preuzeto sa http://www.icj-cij.org/.../index.php?p1... case, 3. X. 2016.

22 Čl. 11. Zakona o rješavanju sukoba zakona s propisima drugih država u određenim odnosima (ZRSZ): „Ako osoba koja je državljanin RH ima i državljanstvo neke druge države, za primjenu ovog zakona smatra se da ima samo državljanstvo RH./Ako osoba koja nije državljanin RH ima dva strana državljanstva ili više stranih državljanstava, za primjenu ovog zakona smatra se da ima državljanstvo one države čiji je državljanin i u kojoj ima prebivalište./Ako osoba iz st. 2. ovog članka nema prebivalište ni u jednoj od država čiji je državljanin, za primjenu ovog zakona smatra se da ima državljanstvo one države čiji je državljanin i s kojom je u najbližoj vezi.“
} 
Način stjecanja državljanstva razlikuje se od države do države ovisno o pravnoj tradiciji, nacionalnim interesima, povijesti i percepciji budućnosti svake države. ${ }^{23}$ Usporednim pregledom različitih zakonodavstava uočava se da se stjecanje državljanstva temelji na jednom od tri načela: načelu krvne veze ili podrijetla (ius sanguinis), načelu područja (ius soli) ili načelu prebivališta (ius domicilii). U pravilu se jedno od navedenih načela uzima kao temeljno, koje se dalje upotpunjava ili modificira drugim dvama načelima te još nekim načinima stjecanja državljanstva.

Po načelu krvne veze ili podrijetla, osoba rođenjem stječe ono državljanstvo koje imaju i njezini roditelji. Ovakav način stjecanja državljanstva preferiraju države s velikim brojem emigranata, kojima je u interesu da očuvaju veze sa svojim iseljenicima, neovisno o tome radi li se o njihovim državljanima ili samo etničkim pripadnicima tog naroda. ${ }^{24}$

Po načelu područja, osoba rođenjem stječe državljanstvo one države na čijem je području rođena. Navedeno načelo u pravilu prihvaćaju imigracijske države jer se njime otvara veća mogućnost naturalizacije i asimilacije stranaca.

Konačno, po načelu prebivališta, osoba stječe državljanstvo države na čijem području prebiva. Ovo načelo prihvaćeno je od strane država koje njeguju kulturni pluralizam i nemaju problema s uključivanjem stranaca putem naturalizacije s pravom da ostanu kulturološki različiti. ${ }^{25}$

Za razliku od nekih prošlih vremena, kada je državljanstvo pretežito označavalo „singularnu afilijaciju određenom pravnom i političkom sustavu“ ${ }^{26}$ državljanstvo u današnjoj Europi, pa i u svijetu, više ne predstavlja homogeni status već se sastoji od nekoliko lako prepoznatljivih elemenata koji se mogu različito kombinirati i generirati različite oblike pravno-političkog života. ${ }^{27}$ Stoga se u novije vrijeme govori o tzv. „rekombiniranom državljanstvu“, kao kontinuumu koji na jednoj strani spektra uključuje i povijesne i rodovske veze, a na drugoj baš nikakve prethodne veze s državom čije se državljanstvo stječe. ${ }^{28}$ "Najslabije“ državljanstvo svodi se isključivo na njegov međunarodnopravni aspekt, na pravni status koji pojedinca povezuje s odgovarajućom državom, bez ikakve stvarne veze s kulturnom i političkom zajednicom te države. Radi se o ,praznom“ konceptu koji, doduše, može formalno biti ispunjen različitim pravima i obvezama, ali konceptualno ne odgovara tradicionalnom poimanju državljanstva.

23 Tako: Mintas-Hodak/Mateša, op. cit., str. 232.

${ }_{24}$ Među spomenute države spada i RH. Tako st. 2. čl. 10. Ustava RH propisuje: „Republika Hrvatska štiti prava i interese svojih državljana koji žive i borave u inozemstvu i promiče njihove veze s domovinom. Dijelovima hrvatskog naroda u drugim državama jamči se osobita skrb i zaštita Republike Hrvatske." Odatle slijedi da RH štiti interese i onih državljana RH koji ne žive ili ne borave na teritoriju RH, a također i interese hrvatskog naroda izvan RH, neovisno o tome imaju li ili ne hrvatsko državljanstvo.

25 Tako: Mintas-Hodak/Mateša, op. cit., str. 232. i 233.

26 Dakle, smatralo se da je moguće biti državljaninom samo jedne države. Vidi: Brubaker, R. W.: „Introduction“, u: Brubaker, R.W. (ur.): Immigration and the Politics oof Citizenship in Europe and North America, Universty Press of America, August 1989, str. 4.

27 Bauböck, R.: Recombinant Citizenship, Reihe Politikwissenschaft, Political Science Series No. 67, Institute for Advaced Studies, Vienna, December 1999., str. 1.

28 Ibidem. 
Dr. sc. Ines Medić: Neka pitanja državljanstva u sportu kao fenomen međunarodnog sportskog prava Zbornik radova Pravnog fakulteta u Splitu, god. 54, 2/2017., str. 415.- 435.

„Najjače“ državljanstvo posebnu težinu stavlja na kolektivni kulturni identitet, tj. na pripadnost državnom poretku kao najvećem i najvažnijem kolektivitetu kojem su subordinirani svi ostali identiteti. Naravno, između ove dvije krajnosti postoji i niz drugih varijanti. ${ }^{29}$

Rekombinirano državljanstvo prisutno je i u sportu, možda i više nego u drugim sferama života. Nastavno na Bauböckovu ideju, a polazeći od najslabije točke kontinuuma, moguće je identificirati nekoliko različitih kategorija: ${ }^{30}$

- Očigledno „najslabije“ državljanstvo egzistira onda kada je sportaš igrao za najmanje tri različite države. Iako je riječ o uvjerljivo najslabijoj državljanskoj vezi (odsustvo i ius sanguinis i ius soli i ius nexi), vrhunski rezultati takvih sportaša osiguravaju im da od strane domaćih navijača budu doživljeni kao dio nacionalnog korpusa. $^{31}$

- Sljedeće u spektru slabih državljanstava jest tzv. „državljanstvo na prodaju“, kada između sportaša i države koju predstavlja nema nikakvih ranijih veza. Niti oni, a niti njihovi preci nisu rođeni u toj državi. Ne postoji niti kolonijalna veza, a niti veza kroz rad ili edukaciju. Radi se o čisto ugovornoj vezi gdje sportaš dobiva putovnicu i državljanstvo (uz, često, izdašan novčani iznos) u zamjenu za medalje i očekivani napredak nacionalnog tima. ${ }^{32}$ Po mišljenju mnogih, riječ je o veoma opasnoj politici koja značajno podriva demokraciju na području EU. ${ }^{33}$

- Prema sredini spektra moguće je svrstati državljanstvo stečeno nakon raspada jedne i nastanka novih država, kao u slučaju bivše Jugoslavije. Državljani bivše države biraju koju će od novonastalih država predstavljati ili biraju neku treću državu, izvan regije kojoj pripadaju. ${ }^{34}$

\section{Ibidem.}

30 Tako: Oonk, G./van Campenhout, G.: Who Belongs to the Nation? Sport, Migration and Citizenship Changes, Preuzeto sa http://www.sportandnation.com, 12. XII. 2016.

31 Jedan od poznatijih primjera je onaj mađarskog nogometaša Laszla Kubale, koji je igrao za tri nogometne reprezentacije - Čehoslovačku, Mađarsku i Španjolsku te još za reprezentaciju Europe i Katalonije u revijalnim utakmicama. Rođen je u Mađarskoj kao i njegovi roditelji. Sa 19 godina preselio se u Čehoslovačku radi izbjegavanja vojne obveze i vjenčao s čehoslovačkom državljankom. Igrao je za čehoslovačku reprezentaciju (1946.-1947.). Po povratku u Mađarsku igrao je za Mađarsku, da bi se 1950. godine preselio u Barcelonu i nakon stjecanja španjolskog državljanstva igrao za Španjolsku (1953.1961.). Preuzeto sa https://hr.wikipedia.org/wiki/Ladislao_Kubala, 3. XII. 2016. Od recentnijih, tu su i: Diego Costa (Brazil, Spanjolska), Michel Platini (Francuska, Kuvajt), Alfredo di Stefano (Kolumbija, Argentina, Španjolska), Ferenc Puskas (Mađarska, Španjolska), Thiago Motta (Italija, Brazil) i Jermaine Jones (Njemačka i SAD). Preuzeto sa http://sport.ba/clanak/199411/najpoznatijih-sedam-fudbalera-kojisu-igrali-za-vise-reprezentacija, 19. X. 2016.

32 Kakvo nude, primjerice Azerbajdžan i Katar, što je bilo i više nego očito na ljetnim Olimpijskim igrama u Riju 2016. godine. Relativno je slabo poznato da je jedan od uživatelja ovog tipa državljanstva, i to Katara, bio i Michel Platini, 1988. godine.

33 Bauböck, R.: Should citizenship be for sale? - What is wrong with selling citizenship? It corrupts democracy! Preuzeto sa http://eudo-citizenship.eu/commentaries/citizenship-forum/citizenship-forumcat/990-should-citizenship-be-for-sale?showall=\&start=6, 23. XII. 2016.

34 Na ljetnim Olimpijskim igrama u Barceloni, 1992. godine, Međunarodni olimpijski odbor je (prvi put) dozvolio sportašima s područja bivše Jugoslavije da se natječu individualno, s obzirom na to da u novonastalim državama još nisu postojali nacionalni olimpijski odbori. Izuzetak su činili sportaši s područja Srbije, Makedonije i Crne Gore kojima nije bilo dozvoljeno natjecanje, jer su u to vrijeme navedene države bile pod UN-ovim sankcijama. Trenutno je aktualno pitanje sportaša s Kosova. Kosovo 
-Relativno čvrstu državljansku vezu ostvaruju migranti ili njihovi preci (pozivanjem na ius nexi ili trajnom interesu za članstvo). Najčešće je riječ o prvoj ili drugoj generaciji migranata - radnika koji su se trajno nastanili i udomaćili u državi primateljici. Mnogi pripadnici ove kategorije već uživaju blagodat dvojnog ili višestrukog državljanstva te su u mogućnosti izabrati koju od država, čije državljanstvo imaju, žele predstavljati. ${ }^{35}$

- U kategoriju relativno jakih nedvojbeno spada „kolonijalno“ državljanstvo, posljedica duge kolonijalne povijesti nekih država te njihovih bliskih političkih i kulturnih veza i u postkolonijalnom periodu. Ovaj se tip državljanstva najčešće temelji samo na ius sanguinis (niti sportaš, a niti njegovi roditelji nisu rođeni u državi koju sportaš predstavlja, ali su rođeni u (bivšoj) koloniji ) ili na olakšanoj naturalizaciji državljana bivših kolonija koji su stupili u brak s državljanima bivše imperije, ali se može temeljiti i na kombinaciji ius soli i ius sanguinis (jedan od roditelja državljanin matične države, a drugi rođen i odgojen na teritoriju kolonije). ${ }^{36}$ Mnoge se europske države i danas pojačano oslanjaju na sportaše iz bivših kolonija, primjerice Velika Britanija, Francuska, ${ }^{37}$ Nizozemska i Portugal. ${ }^{38}$

- Najjače (idealno) državljanstvo utemeljeno je podjednako na ius soli i ius sanguinis, s naglaskom na pripadnost državnom poretku kao najvećem i najvažnijem kolektivitetu kojem su subordinirani svi ostali identiteti. Ideju o njegovoj „čvrstoći“ dodatno potiču i patriotske izjave sportaša o ,časti da predstavljaju državu u kojoj su rođeni“ ili „prilici da se oduže državi za ulaganje u njihove sportske uspjehe“. ${ }^{39}$ Ipak, malo dublji uvid ispod površine pokazuje da se čvrstoća i ovih veza može razlikovati od slučaja do slučaja. Primjerice, pored sportaša koji su i rođenjem i

je 3. V. 2016. postalo članicom UEFA-e, te će imati pravo sudjelovati u kvalifikacijama za Europsko prvenstvo 2020. godine. Već 13. V. 2016. Kosovo je primljeno i u članstvo FIFA-e, pa bismo državnu reprezentaciju Kosova mogli gledati i u kvalifikacijama za SP u Rusiji 2018. godine. Međutim, igrači koji su u periodu od članstva u UEFA-i igrali za drugu reprezentaciju, nakon 13. V. 2016. ne mogu više promijeniti ,sportsko državljanstvo“.

35 Na području Europske unije to su uglavnom migranti, čiji potomci imaju dvojno državljanstvo. Tako, Thiago Motta, Brazilac koji je igrao za Italiju (mada je češće riječ o Marokancima i Turcima). To pravilo ima i iznimki. Primjerice, u slučaju kada strani sportaš nakon 5 godina igranja za klubove neke države naturalizacijom stječe državljanstvo te države i tako se kvalificira kao podoban za nacionalni tim. To, međutim, nerijetko dovodi do osude sportaša od strane navijača njegove bivše države. Tako, Diego Costa, Brazilac koji je igrao za Španjolsku. Vidi: Simon, R. L.: „Theories of Sport“, u: Torres. C. (ed.): A Companion to the Philosophy of Sport, Bloomsburry Press, London, 2014.

36 Primjera u sportskoj praksi ima dosta. Tako su 1924. i 1928. britanski hokejaški olimpijski tim uglavnom sačinjavali kanadski vojni službenici i studenti koji su živjeli u Velikoj Britaniji. Čak i nakon 1936. godine i odluke da nacionalni tim moraju sačinjavati osobe koje su rođene u Velikoj Britaniji, tim je uključivao jednog sportaša rođenog u Kanadi, devet igrača odraslih u Kanadi te jedanaest igrača koji su ranije igrali za Kanadu, sve redom osobe koje su imale britansku putovnicu, ali su živjele i radile u Kanadi. Preuzeto sa http://www.greatesthockeylegends.com/2010/01/1936-olympics-garmisch-partenkirchen. html, 10. XII. 2016.

37 Čini se ipak da u Francuskoj taj trend posustaje. Vidi: http://www.bbc.com/sport/rugbyUnion/38389827, preuzeto 5. I. 2017.

38 Vidi: Podnar, O.: Foreign legions. When it comes to selecting for national success, picking naturalized players knows no borders. Preuzeto sa http://www.soccerphile.com/soccerphile/news/ balkans-soccer/naturalized.html, 12. X. 2016., str. 2-6.

39 Oonk/van Campenhout, op. cit., bilj. 30. 
porijeklom vezani isključivo za državu za koju igraju, u istu kategoriju spadaju i oni sportaši čiji su roditelji različitog državljanstva pa pored državljanstva stečenog temeljem ius soli u kumulaciji s ius sanguinis, imaju i državljanstvo drugog roditelja stečeno temeljem ius sanguinis što im omogućava da biraju državu za čiji će nacionalni tim nastupati. ${ }^{40}$

Iz svega navedenog, više je nego očigledno da su globalizirano tržište i transnacionalizacija državama otvorili mogućnost prilici za selekciju, pripremu i visoko kvalitetan trening te „državljanski turizam“. ${ }^{41}$ Taj proces je dodatno olakšan oslobađanjem države od nacije i svođenjem nacionalizma na banalnost, ${ }^{42}$ a sve kako bi se olakšali priznanje i prestiž u globaliziranom svijetu.

Dvojno državljanstvo više nije anomalija ${ }^{43}$ nego uobičajena pojava, a nacionalna identifikacija više nije isključivi garant prava. ${ }^{44} \mathrm{U}$ takvim okolnostima, ,liberalne demokratske države nemaju drugog izbora nego poštovati temeljna ljudska prava svih osoba na njihovom teritoriju, a državljani su socijalni agenti s pripadajućim pravima te uživaju višestruke identifikacije i povratno članstvo u različitim, koegzistirajućim, krugovima pripadanja“". ${ }^{45}$ Jednako tako, niti sportaši više nisu isključivo predstavnici države, nego ujedno i reklama za proizvod, magnet za globalne oglašavajuće kampanje i slavne osobe. ${ }^{46}$

\section{SPORT I DRŽAVLJANSTVO}

Još od ranog 19. stoljeća, sport igra dominantnu ulogu u strukturiranju političkog entiteta nacije. Gdje god se u Europi pojavio nacionalni pokret ujedinjenja, nicali su i sportski klubovi kao simbol patriotizma. Štoviše, „moć sporta unutar nacionalne identifikacije također se može mjeriti u odnosu na njegov kapacitet da reinterpretira zajedničku viziju nacije“". ${ }^{7}$

Pored toga, sport je, ,kao kolektivno podržavana simbolična struktura, moćna metafora koja otkriva najdublje ukorijenjene vrijednosti neke kulture“". ${ }^{48}$ Brojne

40 Tako je primjerice Jürgen Klinsmann, Nijemac, trener američkog nogometnog tima, 2014. godine sastavio tim od pretežito dvojnih državljana, sportaša s njemačkim i američkim državljanstvom. Preuzeto sa http://www.sportskeeda.com/amp/football/the-us-national-football-team-winning-ugly, 3. XI. 2016.

41 Kostakopoulou/Schrauwen, op. cit., str. 4.

42 Billig, M.: Banal Nationalism, Sage, London, 1995.

43 Spiro, J. P.: „Dual citizenship as Human Right“, International Journal of Constitutional Law, Vol. 8, No. 1, 2010., str. 111.

44 Kostakopoulou/Schrauwen, op. cit., str. 4.

45 Kostakopoulou, D.: „Towards a Theory of Constructive Citizenship in Europe“, Journal of Political Philosophy, Vol. 4, No. 4, 1994., str. 337.

46 Kostakopoulou/Schrauwen, op. cit., str. 4.

47 Xypolia, I.: „More than just a game: football as the modern opium of the masses“, London Progressive Journal, 20th June 2012.

48 Houlihan, B.: „Sport, national identity and public policy“, Nations and nationalism, Vol. 3, No. 1, 1997., str. 116. i ondje navedeni autori. 
države iz godine u godinu pojačano ulažu u sport, upravo imajući u vidu ulogu sporta u promociji nacionalnog identiteta i njegovoj projekciji u inozemstvu. Moglo bi se reći da je to posljedica pojačane svijesti i sumnje u globalizaciju, a također i dramatičnih promjena u globalnoj politici. Zašto?

Zato što je globalizacija proces koji rezultira produkcijom tzv. „treće“ kulture koju je moguće opisati kao transkulturalnu i anacionalnu. ${ }^{49}$ Kako globalna kultura nije autoreferentna i namjerno izbjegava bilo kakav vremenski i povijesni kontekst, i moćne i slabe države suočavaju se s problemom pojačane kulturne nesigurnosti. Stoga ne čudi ponovno okretanje većine zapadnih država prema politici nasljeđa i želji za zaštitom većine tradicionalnih sportova. ${ }^{50}$ Sport i, osobito, elitni sportski uspjesi, koriste se kao zamašnjak osnaživanja nacionalnog jedinstva i razvoja snažnijeg osjećaja nacionalnog identiteta.

To se pokazuje veoma važnim u slučaju novonastalih država, i to kako na domaćoj, tako i na međunarodnoj sceni. Na domaćoj razini, sport stvara osjećaj pripadnosti zajednici unutar te države, koja može koincidirati i s nacionalnim i s etničkim identitetom pojedinca. Na međunarodnoj razini, sport omogućuje: razlikovanje identiteta te države od svih ostalih, unutarnje jedinstvo zajednice postignuto kroz državne simbole te osjećaj nacionalnog uspjeha u međunarodnoj areni. ${ }^{51}$

Državljanstvo je, u svojoj biti, društvena odgovornost. Sport se koristi da poduči, simbolizira i ostvaruje državljanstvo. ${ }^{52}$

\section{DRŽAVLJANSTVO KAO UVJET ZA NASTUPANJE ZA NACIONALNU REPREZENTACIJU}

Najjasnija veza između državljanstva i sporta upravo je zahtjev da sportaši moraju posjedovati državljanstvo određene države da bi je mogli predstavljati na međunarodnim natjecanjima. ${ }^{53}$ Stoga, ukoliko ne posjeduju državljanstvo određene države, preostaje im naturalizacija, odnosno primanje u državljanski status. Iako gotovo svaka država (s ciljem što brže naturalizacije vrhunskih sportaša) može odlučiti da ne inzistira na svim propisanim uvjetima, veoma često sportaši slijede uobičajeni proces naturalizacije. Razlozi za to nalaze se prvenstveno u pravilima o podobnosti međunarodnih sportskih federacija. Pri odlučivanju o podobnosti sportaša da nastupi za određeni nacionalni tim, međunarodna tijela koja rukovode

49 Ibidem.

50 Ibidem.

51 Tako: Dzankic, J.: Sportizenship: the complex links between citizenship, sports and national identity, str. 2. Preuzeto sa http://www.citsee.eu/citsee-story/sportizenship-complex-linx-betweencitizenship-sports-and-national-identity.

52 Guschwan, M. (ed.): Sport and Citizenship, Routledge, 2015.

53 Dzankic, op. cit., str. 4. 
takvim natjecanjima uglavnom podržavaju načelo ,istinske veze“ s državom, ${ }^{54}$ možda više i od samih država. ${ }^{55}$

Propisi o državljanstvu sportaša koji mogu nastupati za državnu reprezentaciju odnosno nacionalni tim sadržani su u propisima nacionalnih i međunarodnih sportskih saveza, a za Olimpijske igre u propisima Međunarodnog olimpijskog odbora i nacionalnih olimpijskih odbora.

Uvidom u pravila FIFA-e, ${ }^{56}$ razvidno je da je ovo pitanje tijekom vremena bilo različito normirano. Dok ranije nije bilo neuobičajeno da igrači nastupaju za različite nacionalne timove, prva je izmjena pravila predviđala da igrač koji je jednom nastupao za nacionalni tim na međunarodnoj utakmici u službenom natjecanju (bez obzira na razinu natjecanja) više ne može igrati za bilo koji drugi nacionalni tim. Nakon ratifikacije novog izmijenjenog Statuta FIFA-e, 2003. godine, ,svaka osoba koja ima državljanstvo određene države podobna je igrati za nacionalni tim te države “. ${ }^{57}$ Naime, temeljno je pravilo i dalje da igrač koji je bio član nacionalnog tima neke države na službenom natjecanju u bilo kojoj kategoriji, ne može igrati na međunarodnoj utakmici za drugu državu. ${ }^{58}$ Međutim, prema odredbama revidiranog čl. 15. novih Pravila FIFA-e koje se odnose na primjenu Statuta, igrač koji je igrao za nacionalni tim jedne države na jednom ili više službenih natjecanja smije, ali samo jednom, zatražiti promjenu države za koju se natječe, i to do 21. godine, pod uvjetom:

- da nije igrao na međunarodnim natjecanjima „A“ razine za državu koju bi mogao predstavljati, u vrijeme podnošenja zahtjeva,

- da je imao dvojno državljanstvo (ili više državljanstava) u vrijeme svog prvog nastupa na međunarodnoj utakmici u službenom natjecanju u bilo kojoj kategoriji.

Ono što je potrebno imati na umu jest da promjena pripadnosti nije dozvoljena tijekom kvalifikacija za natjecanja FIFA-e, kontinentalno prvenstvo ili Olimpijske igre ako je igrač već sudjelovao u utakmici na jednom od tih natjecanja. ${ }^{59}$

Pravila FIFA-e dopuštaju još jedan izuzetak od općeg pravila. Tako, bilo koji igrač koji već ima ispunjene uvjete za igranje za jedan savez ali je temeljem zakona stekao drugo državljanstvo, ima pravo na promjenu saveza. ${ }^{60}$

54 U skladu s odlukom u predmetu Nottebohm (1955.), to znači da sportaš mora dokazati da je „bliže povezan sa stanovništvom države čije državljanstvo stječe, nego i sa jednom drugom državom“.

55 Dzankic, op. cit., str. 4.

56 Fédération Internationalle de Football Association.

57 Čl. 15.1. FIFA 2003 Pravila koja se odnose na primjenu Statuta.

58 Čl. 15.2. FIFA 2003 Pravila koja se odnose na primjenu Statuta.

59 Čl. 15.3. FIFA 2003 Pravila koja se odnose na primjenu Statuta.

60 Za primjer možemo uzeti afričke nogometaše koji su u mladosti igrali za Francusku, ali su naknadno zatražili promjenu pripadnosti. Tako: „Dual nationality“: initial benefits of new FIFA Statutes already evident, 8. I. 2004., www.fifa.com Isto tako, možemo spomenuti i britanske državljane rođene u Sjevernoj Irskoj, koji redovito uzimaju irsko državljanstvo i igraju za irski nacionalni tim, oko čega je u praksi bilo dosta prijepora. Vidi: http://playereligibilityinireland.blogspot.hr/2011/06/fifa-playereligibility-in-context-of.html, preuzeto 3. XI. 2016. 
Međutim, primjena odredbi čl. 15. Pravila FIFA-e koje se odnose na primjenu Statuta isključena je u slučaju da se radi o igračima koji su državljanstvo stekli naturalizacijom nakon što su već igrali za nacionalni tim države svojeg ranijeg državljanstva. Naime, ti se igrači i nakon promjene državljanstva, za potrebe sporta, i dalje smatraju državljanima države čije su državljanstvo imali prije naturalizacije. ${ }^{61}$

Kao što je već spomenuto, slična pravila vrijede i u košarci. Prema Pravilima FIBA-e, ${ }^{62}$ samo igrač koji ima državljanstvo neke države i koji zadovoljava uvjete propisane odgovarajućim internim pravilima može igrati za nacionalni tim te države.$^{63} \mathrm{U}$ pogledu igrača s dva ili više državljanstava (bilo stečenih rođenjem ili naturalizacijom), predviđena je mogućnost izbora za koji nacionalni tim žele igrati. Međutim, ako je igrač već izabran u nacionalni tim jedne od država čije državljanstvo ima, nakon što je napunio 18 godina, obvezan je izjasniti se za koji nacionalni tim želi igrati. ${ }^{64}$

Nadalje, i Pravila FIBA-e sadrže presumpciju da je bilo koji košarkaš koji je na službenim natjecanjima igrao za nacionalni tim neke države izabrao nacionalni tim te države. U svakom slučaju, i izričiti i presumirani izbor su neopozivi. ${ }^{65}$

Jednako kao u nogometu, i Pravila FIBA-e izrijekom navode da igrač nakon što je igrao kao junior, mlađi senior ili senior za nacionalni tim neke države u glavnom službenom natjecanju FIBA-e, ne može ni pod kojim okolnostima igrati za nacionalni tim bilo koje druge države. ${ }^{66}$ Međutim, predviđena je jedna iznimka. Ukoliko postoji izričiti sporazum između dvaju nacionalnih saveza, FIBA može dopustiti igraču koji je kao junior igrao za nacionalni tim u službenom natjecanju FIBA-e, da igra za nacionalni tim druge države čije je državljanstvo stekao. Međutim, to je moguće samo jednom u životu igrača, i taj isti igrač više ne može ponovno igrati za tim države za koju je igrao ranije. ${ }^{67}$ Pravila FIBA-e, nadalje, predviđaju da nacionalni tim koji sudjeluje u međunarodnom natjecanju smije imati samo jednog igrača koji je državljanstvo te države stekao naturalizacijom ili na drugi način, nakon što je napunio 16 godina. ${ }^{68}$

${ }_{61} \mathrm{Na}$ razini kluba, problema u praksi nema. Tako, igrač koji je naturalizacijom stekao novo državljanstvo ima pravo sudjelovati i na domaćim i na međunarodnim klupskim natjecanjima na isti način kao i drugi domaći državljani.

62 Fédération Internationalle de Basketball Association.

63 Čl. 3.3.1. FIBA 2002 Pravila koja se odnose na državljanski status igrača.

${ }^{64}$ Ako igrač odbije poziv da igra za nacionalni tim države koja ga je pozvala, još uvijek može odlučiti da želi igrati za nacionalni tim druge države čije državljanstvo ima, osim ako se (u roku od 15 dana od dana primitka poziva) pismeno izjasni da ipak optira za nacionalni tim države koja ga je prva pozvala. Tako čl. 3.3.2. FIBA 2002 Pravila koja se odnose na državljanski status igrača.

65 Čl. 3.3.2. FIBA 2002 Pravila koja se odnose na državljanski status igrača.

66 Čl. 3.3.4. FIBA 2002 Pravila koja se odnose na državljanski status igrača.

67 Čl. 3.3.5. FIBA 2002 Pravila koja se odnose na državljanski status igrača.

68 Čl. 3.3.3. FIBA 2002 Pravila koja se odnose na državljanski status igrača. Navedeno ne utječe na međunarodna natjecanja klubova jer kompozicija klupskih timova nije podložna ograničenjima u odnosu na državljanstvo igrača. Postavljanje ili nepostavljanje restrikcija u odnosu na klubove u cijelosti je u domeni nacionalnih saveza. Čl. 3.4. FIBA 2002 Pravila koja se odnose na državljanski status igrača. 
Pravila IAAF-a, ${ }^{69}$ kojima se, između ostalog, regulira i pitanje državljanstva sportaša, atletičara, dosta su fleksibilnija od gore navedenih. Naime, temeljno je pravilo da za vrijeme Olimpijskih igara, Svjetskog prvenstva, Svjetskog kupa, kontinentalnih prvenstava i drugih važnih međunarodnih susreta, nacionalne saveze koji su članovi IAAF-a mogu predstavljati samo državljani države kojoj savez pripada. ${ }^{70}$ Dakle, ako je sportaš sudjelovao kao predstavnik određenog nacionalnog saveza u bilo kojem od navedenih natjecanja, on u načelu više ne može predstavljati niti jednu drugu državu na takvom natjecanju.

Međutim, i pravila IAAF-a dopuštaju određene iznimke od općeg pravila. Radi se o sljedećim okolnostima: pripajanje jedne države drugoj, stvaranje nove države stvorene Ugovorom, stjecanje novog državljanstva, ${ }^{71}$ višestruko državljanstvo. ${ }^{72}$

Što se tiče sudjelovanja na Olimpijskim igrama, čl. 41. Olimpijske povelje Međunarodnog olimpijskog odbora iz 2011. godine, ${ }^{73}$ predviđa da svaki natjecatelj na Olimpijskim igrama mora biti državljanin države čiji ga nacionalni Olimpijski odbor prijavljuje za Olimpijske igre. Ukoliko je natjecatelj državljanin dviju ili više država istodobno, može nastupati za svaku od njih prema vlastitom izboru. Međutim, ako je već predstavljao jednu od tih država na Olimpijskim igrama, na kontinentalnim ili regionalnim natjecanjima ili na svjetskom ili regionalnom prvenstvu koje priznaje odgovarajući međunarodni sportski savez, ne smije nastupiti za drugu državu dok ne protekne rok od najmanje tri godine otkako je nastupao za odnosnu državu. Nacionalno olimpijsko tijelo i odgovarajući nacionalni sportski savez ovlašteni su ovaj rok skratiti ili ukinuti.

Navedeni konkretni primjeri možda najbolje pokazuju u kojoj mjeri međunarodni sportski savezi različito pristupaju problemu natjecanja sportaša s dvostrukim ili višestrukim državljanstvom. Unatoč tome, moguće je izvući neke generalne zaključke. Tako, postoji generalni konsenzus oko toga da sportaš koji je na bilo koji način stekao državljanstvo neke države ima pravo natjecati se za njezin nacionalni tim. Međutim, ako je odnosni sportaš već sudjelovao u međunarodnim utakmicama kao igrač nacionalnog tima države čije državljanstvo ima, u pravilu (uz neke vrlo ograničene iznimke koje variraju od saveza do saveza) nema pravo natjecati se za nacionalni tim druge (drugih) država čije državljanstvo ima. Razloga za ovakav stav ima više, no čini nam se da je jedan od najjačih uloga nacionalnog tima kao takvog. Naime, gotovo svaki sportski savez gleda na izbor igrača u

69 International Association of Athletics Federations.

70 Čl. 12.1 toč. a), b) i d) Statuta IAAF-a.

71 U slučaju stjecanja novog državljanstva, sportaš se ne može natjecati za tu državu do isteka najmanje tri godine od datuma kad je posljednji put predstavljao neku drugu članicu saveza u jednoj od kategorija predviđenih u čl. 12.1 toč. a), b) i d) Statuta IAAF-a. Iznimno, ukoliko se odnosni savezi tako dogovore, taj rok može biti sveden na jednu godinu.

72 Ukoliko sportaš ima ili može imati dva ili više državljanstava, smije se natjecati za drugi savez ako je prošlo najmanje tri godine od datuma kad je posljednji put predstavljao neku drugu članicu saveza u jednoj od kategorija predviđenih u čl. 12.1 toč. a), b) i d) Statuta IAAF-a. Iznimno, ukoliko se odnosni savezi tako dogovore, taj rok može biti sveden na jednu godinu.

73 Olympic Charter, in force as from 8 July 2011, www.olympic.org/.../olympic_charter_en.pdf. 
nacionalni tim kao na najveću počast koju igrač uopće može doživjeti u svojoj karijeri. Po mišljenju određenih saveza, da bi igrač zaslužio počast predstavljanja svoje države u međunarodnim utakmicama, nije dostatno samo to da ima njezino državljanstvo te da je jedan od najboljih sportaša u svojoj generaciji. Od igrača se također traži da dokaže postojanje posebne veze s tom državom. ${ }^{74}$ Ta se veza, u načelu, predmnijeva u slučaju igrača koji su državljanstvo stekli rođenjem. Samo manji broj saveza polazi od pretpostavke da već samo posjedovanje određenog državljanstva (neovisno o načinu stjecanja) samo po sebi uključuje nužnu vezu s određenom državom. U većem broju slučajeva sportaši s dvostrukim ili višestrukim državljanstvom, odnosno naturalizirani sportaši, moraju čekati protek određenog vremenskog perioda da bi uopće mogli igrati za drugu državu čije državljanstvo također imaju.

\section{NATURALIZIRANI SPORTAŠI I SPORTAŠI S DVOJNIM DRŽAVLJANSTVOM}

U današnje vrijeme sve češće svjedočimo pojavi da klubovi iz država koje nemaju dovoljno vlastitih vrhunskih sportaša kupuju ili na drugi način nastoje pridobiti vrhunske strane sportaše $u$ vlastite redove..$^{75}$ Najčešće se tu radi o stranim sportašima koji su članovi nacionalnih sportskih timova država čiji su državljani, a od kojih se očekuje da bi mogli nastupati za nacionalni tim države u koju dolaze kao sportaši stranci. Između ostaloga, i u tu svrhu, sva nacionalna zakonodavstva u svojim propisima o državljanstvu predviđaju mogućnost naturalizacije stranih sportaša, ponekad čak i pod povoljnijim uvjetima od drugih kategorija stranaca.

Razlozi zbog kojih se sami sportaši odlučuju promijeniti državljanstvo mogu biti dosta šaroliki. To mogu biti privatni razlozi (poput braka, financijskih i drugih povlastica, želje za integracijom u novu sredinu itd.) ili razlozi vezani uz javni interes države čije državljanstvo stječu (poput potreba određenog kluba, pridobivanje vrhunskog igrača itd.). Međutim, u novije vrijeme javljaju se i neki novi motivi.

74 Tako: Van den Bogaert, S.: „Practical Regulation of the Mobility of Sportsmen in the EU Post Bosman", Kluwer Law International, 2005., str. 353.

75 Jedan od takvih primjera svakako je i Katar. U tome ide toliko daleko da stranim sportašima praktički ne nameće bilo kakva ograničenja za stjecanje katarskog državljanstva, a nerijetko nudi i veće količine novca s ciljem pridobijanja stranaca da se natječu pod katarskom zastavom. Praktične primjere nam, zapravo, i ne treba tražiti daleko. Svojedobno su sve tiskovine izvještavale o tome da je srebrnom olimpijcu splitskog Poška i riječkog Primorja, plivaču Duji Draganji bilo ponuđeno da, uz veliku naknadu, 2006. godine ode u Katar. S obzirom na to da je uvjet bio da se odrekne hrvatskog i primi katarsko državljanstvo, Draganja je odbio i nastavio nastupati za hrvatski klub Primorje. Nagađalo se da je sličnu ponudu dobila i Blanka Vlašić, no i ona se očigledno zahvalila i odbila. (Više o tome i o drugim sličnim primjerima vidi u: Mintas-Hodak/Mateša, op. cit. str. 248. i 249.). Ovakva nekorektna praksa Katara ponukala je IAAF da na agendu svojeg godišnjeg kongresa u Helsinkiju 2005. godine, stavi i pitanje trgovanja državljanstvom. (Više o tome vidi u: Vandeputte, F.: ,Olympisch virus van nationaliteitwissels“", De Standaard, 26 August 2004.). Pored toga, neki od sportskih saveza odlučili su postrožiti svoja pravila za sudjelovanje igrača u reprezentacijama. Tako, npr. FIBA (Fédération Internationale de Volleyball), FIFA itd. (Vidi: Van den Bogaert, op. cit., str. 359). 
Dr. sc. Ines Medić: Neka pitanja državljanstva u sportu kao fenomen međunarodnog sportskog prava Zbornik radova Pravnog fakulteta u Splitu, god. 54, 2/2017., str. 415.- 435.

Tako neki sportaši uzimaju državljanstvo neke od država članica EU da bi lakše prelazili u druge europske klubove. ${ }^{76}$

Međutim, sportaši koji su državljanstvo stekli naturalizacijom te sportaši s dvojnim državljanstvom čine posebnu kategoriju sportaša koji se nerijetko suočavaju s diskriminacijom na temelju državljanstva, unatoč činjenici da posjeduju pravno državljanstvo države članice u kojoj su izvrgnuti diskriminaciji. Naime, ove kategorije sportaša u praksi često imaju probleme vezane uz sudjelovanje u nacionalnom timu. ${ }^{77}$ To je osobito vidljivo npr. u nogometu ili košarci.

Neki smatraju da je postojeći režim izrazito nepošten te da svako ograničenje u pogledu državljanstva, s obzirom na činjenicu da su države limitirane brojem sportaša koje mogu poslati na natjecanja u pojedinim sportovima, rezultira time da neki izuzetni sportaši ne mogu sudjelovati. Ističu laissez-faire pristup nastupanju za državnu reprezentaciju kao jedini pristup koji sportaše stavlja u položaj jednakosti. ${ }^{78}$ Također ističu da nema mjesta kritici olakšane naturalizacije jer je doprinos takvih vrhunskih sportaša državi dostatan da nadomjesti nepostojanje ranije teritorijalne veze. ${ }^{79}$ Zagovornici ukidanja državljanstva kao uvjeta za članstvo u nacionalnom timu smatraju da bi dres koji igrač nosi trebao biti dostatan dokaz lojalnosti sportaša, kako za igrače, tako i za navijače. ${ }^{80}$

Drugi, pak, smatraju da se jačanjem individualne dimenzije sporta podcjenjuje ulaganje države u sportaša i njegov razvoj te značajan doprinos njegovanju njegova talenta; obezvređuje državljanstvo jer ga se degradira na nivo razmjene i sporazuma; političkom životu oduzimaju priče o slavi, „herojskim pobjedama“ na sportskim

76 Jedan od primjera je argentinski Hrvat, Daniel Biloš, koji je po vlastitoj izjavi uzeo hrvatsko državljanstvo kako bi sebi otvorio vrata prema europskim klubovima. Unatoč postojanju zakonskih pretpostavki, moralnost tog Biloševa čina vrlo je upitna s obzirom na to da je 2006. godine odbio igrati za hrvatsku nogometnu reprezentaciju na Svjetskom prvenstvu iako ga Argentina tada uopće nije tražila u svoju reprezentaciju. Više o tome vidi u: Mintas-Hodak/Mateša, op. cit. str. 249.

77 Za primjer možemo uzeti nogometaša Tima Cahilla, rođenog u Australiji, čija majka potječe sa Samoe, otac iz Engleske, ali ima škotske i irske korijene. Teoretski, Tim je mogao igrati za pet različitih nacionalnih timova. U mladosti je igrao za Samou, nakon što je Australski nogometni savez jamčio obitelji da to neće predstavljati problem za njegovu podobnost da igra za Australiju. Međutim, nakon što je igrao kao profesionalni nogometaš u Engleskoj i bio odabran da na Olimpijskim igrama koje su se održavale 2000. godine u Sydneyu predstavlja Australiju, rečeno mu je da nije podoban da predstavlja Australiju. Nakon što Cahill nije htio odustati, FIFA je 2003. godine, na izvanrednom kongresu ratificirala novi Statut koji je stupio na snagu 1. siječnja 2004. godine, na način da igrač koji je igrao za nacionalni tim jedne države na jednom ili više službenih natjecanja smije samo jednom zatražiti promjenu države za koju se natječe, i to do 21. godine, pod uvjetom:

- da nije igrao na međunarodnim natjecanjima „A“ razine za državu koju bi mogao predstavljati, u vrijeme podnošenja zahtjeva,

- da je imao dvojno državljanstvo (ili više državljanstava) u vrijeme svog prvog nastupa na međunarodnoj utakmici u službenom natjecanju u bilo kojoj kategoriji. Tako: Van den Bogaert, op. cit., str. 348 .

78 Gomberg, P.: „Patriotism in Sports and in War“, u: Tannsjo, T./Tamburrini, C. (ur.): Values in Sport: Elitism, Nationalism, Gender Equality and the Scientific Manufacture of Winners, Spon Press, New York, 2000., str. 87-97. i Gomberg, P.: „Patriotism is Like Racism“, u: Primoratz, I. (ur.): Patriotism, Humanity Books, New York, 2002., str. 105-112.

79 Kostakopoulou/Schrauwen, op. cit., str. 23.

80 Spiro, P.: „Eliminating Nationality Rules“, The New York Times, December 6, 2012. 
natjecanjima te narativne konstrukcije o jedinstvenom nacionalnom ili državnom karakteru i, konačno, da se time dokida razlika između svjetskog prvenstva i Olimpijskih igara. ${ }^{81}$ Stoga smatraju da je zaustavljanje takve prakse odgovornost ne samo država, nego i Međunarodnog olimpijskog odbora. Pozivaju se na činjenicu da prve tri Olimpijske igre modernog doba nisu uključivale nacionalne timove, već su se sportaši natjecali individualno. Državljanstvo je postalo bitno tek od 1908. godine, kad je nacionalnim Olimpijskim odborima dana mogućnost selekcije sportaša koji ce se natjecati na Olimpijskim igrama. ${ }^{82}$ Stoga bi upravo Međunarodni olimpijski odbor trebao inzistirati na uvjetima koji će odaslati jasnu poruku kako državljanstvo u sportu i dalje treba zadržati svoj značaj. Kao minimalni period potreban za naturalizaciju, spominje se 7 godina boravka u državi čije se državljanstvo traži, osim iznimno, u slučaju političkih azilanata te osoba koje su sklopile brak i preselile se u odnosnu državu, u kom slučaju se predlaže rok od tri godine. Iznimka bi bili i sportaši s dvojnim državljanstvom, kojima bi se omogućilo da do 18. rođendana izaberu državu koju žele predstavljati, bez naknadne mogućnosti predomišljanja. ${ }^{83}$

\section{DISKRIMINACIJA TEMELJEM DRŽAVLJANSTVA I IGRANJE ZA NACIONALNI TIM}

Pitanje diskriminacije stranih sportaša jedna je od top-tema tzv. „europske dimenzije sporta“ ". ${ }^{84}$ Međutim, u skladu sa zapažanjem dualističke prirode sporta (nacionalizma koji se manifestira prema van i patriotizma koji se manifestira prema unutra), ${ }^{85}$ uočeno je i da su akcijski planovi za razvoj europske dimenzije sporta $^{86}$ uglavnom usmjereni na područje EU, dakle prema unutra ${ }^{87}$ što je logična posljedica aspiracije ka zajedničkom europskom identitetu i dijeljenju ,građanskog“ patriotizma. To u velikoj mjeri objašnjava posvećenost EU zabrani diskriminacije temeljem državljanstva, ali zato ostavlja otvorenim pitanje u kojoj mjeri tzv.

81 Tako: Kostakopoulou/Schrauwen, op. cit., str. 30.

82 Tako: Wilson, N.: The thorny issue of athletes changing nationality. Preuzeto sa http://www. sportfeatures.com/olympicsnews/story/49393/neil-wilson-the-thorny-issue-of-athletes-changingnationality.

83 Ibidem.

84 Vidi: Weatherill, S.: „Discrimination on Grounds of Nationality in Sport“, u: Weatherill, S.: European Sports Law, Asser International Sports Law Series, 2014, str. 21-62.

85 Bonikowski, B.: „Research on American Nationalism“, Review of the Literature, Anotated Bibliography, and Directory of Publicly Available Data Sets, RSF Working Paper Series, Russell Sage Foundation, Princeton, 2008. Preuzeto 15. XI. 2016., sa http://www.rusellsage.org/sites/all/files/u4/ Bonikowski\%20\%26\%20DiMaggio_American\%20Nationalism.pdf.

86 Kostakopoulou/Schrauwen, op. cit., str. 9-10.

87 Tako se navode: poboljšanje javnog zdravlja, borba protiv dopinga, volontiranje, socijalna inkluzija itd. Vidi: Accompanying document to the White Paper on Sport COM (2007) 391 final - Action Plan „Pierre de Coubertin“, Brussels, 11. July 2007. 
Dr. sc. Ines Medić: Neka pitanja državljanstva u sportu kao fenomen međunarodnog sportskog prava Zbornik radova Pravnog fakulteta u Splitu, god. 54, 2/2017., str. 415.- 435.

„europsko državljanstvo“ mijenja percepciju državljanstva kao posebne veze između pojedinca i države kojoj pripada. ${ }^{88}$

Još 1974. godine, u predmetu Walrave and Koch, Sud EU (dalje: CJEU) ${ }^{89}$ izrijekom je potvrdio da je sportska aktivnost podložna pravu Zajednice samo u onoj mjeri u kojoj predstavlja ekonomsku aktivnost u smislu čl. 2. Ugovora o EZu. ${ }^{90}$ Pitanje zabrane diskriminacije ne odnosi se na sastav sportskih timova, osobito nacionalnih, čija je formacija pitanje od isključivo sportskog interesa ${ }^{91}$ te kao takva nema nikakve veze s ekonomskom aktivnosti. ${ }^{92}$

To je potvrdio i dvije godine poslije, u predmetu Donà,${ }^{93}$ a također i u predmetu Bosman. ${ }^{94}$ Međutim, iako je podržao takvo tumačenje kao „očito i uvjerljivo“, nezavisni odvjetnik Lenz nije propustio istaknuti da je riječ o iznimci koja nije utemeljena u Ugovoru o EZ-u (javni poredak, javna sigurnost ili javno zdravlje) te ju je stoga iznimno teško obrazložiti, osobito imajući u vidu da i igranje za nacionalni tim ima značajne financijske reperkusije i da ne spada $u$,,neekonomsku“ aktivnost. ${ }^{95}$ Pored toga, istakao je nezavisni odvjetnik Lenz, nacionalni aspekt upitan je i s aspekta navijača i izbornika, jer niti oni uvijek ne udovoljavaju kriteriju državljanstva. ${ }^{96}$ Iz te perspektive, pitanje državljanstva kao uvjeta za igranje za nacionalni tim moguće je objasniti isključivo kao čisto sportsko pravilo, jednako bilo kom drugom sportskom pravilu. ${ }^{97}$

S obzirom na to da Unija nije ovlaštena zadirati u pravo nacionalnih država da same kontroliraju kome će i pod kojim uvjetima dodijeliti svoje državljanstvo, jedino daljnja transnacionalizacija može biti pokretač revizije predmnijevane veze između odanosti, identiteta i državljanstva. Državljanstvo Europske unije, utemeljeno na ,postojanju zajednice država i pojedinaca koji dijele iste vrijednosti, visok stupanj uzajamnog povjerenja i posvećenost solidarnosti““, ${ }^{98}$ samo po sebi ne oslabljuje državljanstvo država članica, ali otvara prostora ideji o mogućoj odanosti dvjema ili većem broju državnih ili političkih zajednica. ${ }^{99}$

88 Kostakopoulou/Schrauwen, op. cit., str. 12.

89 Coourt of Justice of the European Union, sa sjedištem u Luxembourghu.

90 CJEU Case 36/74 Walrave and Koch v. Association Union Cycliste Internationale [1974] ECR 1405, para. 4. Odluke.

91 Vidi: Weatherill, S.: „On overlaping legal orders: what is the „purely sporting“ rule?“, u: Bogusz, B./Cygan, A./Szyszczak, E. (ur.): The Regulation of Sport in the European Union, Edward Elgar Publishing, 2007., str. 48-73.

92 Ibidem, para. 8. Odluke.

93 CJEU Case 13/76 Gaetano Donà v. Mario Mantero [1976] ECR I 1333, para. 14.

94 CJEU Case C-415/93 Union Royale Belge Sociétés de Football Association and others v. Bosman and others [1995.] ECR I-4921, para. 73.

95 Opinion of AG Lenz ( u predmetu C-415/93 Bosman), delivered on 20 September 1995, para. 139.

96 Ibidem, para. 143.

97 Tako: Kostakopoulou/Schrauwen, op. cit., str. 15.

98 Opinion of AG Villalón (u predmetu C-47/08 Commission v. Belgium), delivered on 14 September 2010, para. 139.

99 Vidi: O'Keeffe, D.: „Judicial Interpretation of the Public Service Exception to the Free Movement of Workers“, u: Curtin, D./O'Keeffe, D. (ur.): Constitutional Adjudication in European Communiity and 
Dr. sc. Ines Medić: Neka pitanja državljanstva u sportu kao fenomen međunarodnog sportskog prava Zbornik radova Pravnog fakulteta u Splitu, god. 54, 2/2017., str. 415.- 435.

$\mathrm{Na}$ tom tragu, sve je glasnija i ideja o tzv. „sportskom državljanstvu“ kao samostalnoj kategoriji, tj. kao državljanstvu koje implicira novi oblik društvenog pripadanja, umjesto tradicionalnog naglaska na nacionalnosti i nacionalnom identitetu. ${ }^{100}$ To, dakako, ne bi isključivalo tradicionalno državljanstvo nego egzistiralo paralelno s njime.

\section{STANJE HRVATSKOG SPORTA}

Što se Hrvatske tiče, zanimljivo je da kao relativno mala država ima velik broj međunarodno afirmiranih vrhunskih sportaša. ${ }^{101}$ Međutim, nesređena situacija u sportskom sektoru uopće (neriješena pitanja organizacije bavljenja sportom, financiranja i odgajanja mladih sportaša itd. $)^{102}$ dovela je do potrebe pojačanog angažiranja stranih profesionalnih sportaša. Stoga ne čudi vrlo velik broj stranih sportaša koji su u posljednjih 20-tak godina zatražili i stekli hrvatsko državljanstvo. ${ }^{103}$

Kad je riječ o hrvatskom državljanstvu, Zakon o hrvatskom državljanstvu iz 1991. godine (ZD) ${ }^{104} \mathrm{u}$ čl. 3., predviđa četiri moguća načina stjecanja državljanstva, i to: podrijetlom, rođenjem na teritoriju $\mathrm{RH}$, prirođenjem i po međunarodnim ugovorima. Primarno načelo za stjecanje hrvatskog državljanstva jest načelo podrijetla ili krvne veze. ${ }^{105}$

Pri stjecanju hrvatskog državljanstva prirođenjem (naturalizacijom) postoji više vrsta situacija. Prije svega, ZD predviđa dvije mogućnosti naturalizacije:

National Law, Butterworth, 1992., str. 105.

100 Harrington, A. R.: Citizenship of Sport, preuzeto sa http://www.jurisculture.net/2010/02/ citizenship-of-sport.html, 15. XI. 2016.

101 „Bez pretjerivanja, malo se koja država čiji je ukupan broj stanovnika jednak ili čak malo manji od broja stanovnika nekog većeg grada (npr. London, Moskva) uopće može pohvaliti s titulama olimpijskog i svjetskog prvaka u nizu elitnih ekipnih sportova (vaterpolo, rukomet, košarka, tenis - Davis kup...) i s nepreglednim nizom titula prvaka i nositelja medalja u pojedinačnoj konkurenciji (Blanka Vlašić, Sandra Perković, Janica Kostelić, Duje Draganja, Goran Ivanišević, Ivica Kostelić....). Unutar gotovo nevjerojatnih rezultata posebno „bodu oči“ skijaši s obzirom na činjenicu da u našoj državi postoji minimalan broj skijaških staza, a za disciplinu spust, na primjer, ne postoji niti jedna, jednako kao što ne postoji niti jedna skijaška skakaonica (za razliku ne samo od susjedne Slovenije s mamut-skakaonicom na Planici, nego i za razliku od susjedne Bosne i Hercegovine koja skakaonicu ima ne samo na Igmanu nego čak i na Vlašiću).“ Tako: Kačer, H.: „(Ne)sportski slučaj Jakova Faka“, Ius-info, 16. XI. 2010. Preuzeto sa www.iusinfo.hr/DailyContent/Topical.aspx?id=8290.

102 O čemu svjedoči i recentni članak u Slobodnoj Dalmaciji - „Za Hrvatsku nije dovoljno dobra, ali jest za svjetske prvakinje“, od 7. XII. 2016. Mlada hrvatska rukometašica Marta Tomac koja je nastupala za mlade hrvatske vrste kasnije nije bila pozivana pa je, dobivši norveško državljanstvo, postala dijelom norveške rukometne reprezentacije.

103 Tako npr. slovenski nogometaš Boštjan Cesar (igrao za NK Dinamo), makedonski nogometaš Goce Sedloski (igrao za Hajduk, pa Dinamo), ukrajinska rukometašica Svitlana Pasičnik (igrala za RK Lokomotiva), ruska odbojkašica Irina Kirilova (igrala za Mladost-Zagreb), Brazilac Eduardo da Silva koji je sa 15 godina došao u juniore NK Dinamo, Brazilac Etto koji je također igrao za Dinamo itd.

104 Zakon o hrvatskom državljanstvu, NN br. 53/91; Zakon o izmjenama i dopunama Zakona o hrvatskom državljanstvu, NN br. 130/11 i Odluka Ustavnog suda Republike Hrvatske br. U-I-206/1992, U-I-207/1992 i U-I-222/1992 od 8. prosinca 1993.

105 Detaljnije o tome vidi u: Borković, I.: Upravno pravo, Zagreb, 1997., str. 158-162. 
prirođenje redovnim putem $^{106}$ i prirođenje pod povoljnijim uvjetima. Prirođenjem pod povoljnijim uvjetima hrvatsko državljanstvo stječu posebne kategorije osoba za koje vrijede blaži uvjeti. ${ }^{107}$

Kriteriji i postupak za davanje mišljenja u svrhu utvrđivanja interesa za Republiku Hrvatsku povodom zahtjeva sportaša stranog državljanstva za stjecanje hrvatskog državljanstva uređeni su Zakonom o hrvatskom državljanstvu i Pravilnikom o davanju mišljenja Hrvatskog olimpijskog odbora o interesu hrvatskog športa povodom zahtjeva športaša stranog državljanstva za davanje potpore stjecanju hrvatskog državljanstva iz 2009. godine. Naime, prema čl. 12. st. 1.ZD-a, stranac čije bi primanje u hrvatsko državljanstvo predstavljalo interes za RH, mora uz zahtjev za stjecanje hrvatskog državljanstva priložiti preporuku, odnosno mišljenje nadležnog ministarstva o postojanju interesa $\mathrm{RH}$ za primitak u hrvatsko državljanstvo. S obzirom na to da utvrđivanje interesa hrvatskog sporta polazi od činjenice da sportaši članovi nacionalnog tima predstavljaju svoj nacionalni sportski savez, hrvatski sport u cjelini i RH u međunarodnim natjecanjima, pripadajući nacionalni sportski savez, u pravilu, traži i mišljenje Hrvatskog olimpijskog odbora. Prema čl. 3. navedenog

106 Prema čl. 8. st. 1. ZD, prirođenjem redovitim putem stranac stječe hrvatsko državljanstvo ako su kumulativno ispunjene sljedeće pretpostavke:

- da je navršio 18 godina života te da mu nije oduzeta poslovna sposobnost,

- da ima otpust iz stranog državljanstva ili da podnese dokaz da će otpust dobiti ako bude primljen u hrvatsko državljanstvo, $\mathrm{RH}$,

- da je do podnošenja zahtjeva imao prijavljen boravak najmanje 5 godina neprekidno na teritoriju

- da poznaje hrvatski jezik i latinično pismo,

- da se iz njegova ponašanja može zaključiti da poštuje pravni poredak i običaje u RH i da prihvaća hrvatsku kulturu.

107 To su:

- osoba koja je rođena na teritoriju Hrvatske, iako ne udovoljava pretpostavkama što se tiče punoljetnosti, tj. poslovne sposobnosti, otpusta iz stranog državljanstva i poznavanja hrvatskog jezika (čl. 9. ZD-a),

- osoba koja je u braku s hrvatskim državljaninom i kojoj je odobreno trajno nastanjenje na području RH iako ne ispunjava pretpostavke koje se inače traže za stjecanje hrvatskog državljanstva (čl. 10. ZD-a),

- iseljenik i njegovi potomci iako ne ispunjavaju pretpostavke koje se inače traže za stjecanje hrvatskog državljanstva (čl. 11. st. 1. ZD-a), ZD-a),

- stranac koji je u braku s iseljenikom koji je hrvatsko državljanstvo stekao prirođenjem (čl. 11. st. 2.

- osoba čije bi primanje u hrvatsko državljanstvo predstavljalo interes RH (kao i njezin bračni drug), iako nisu ispunjene pretpostavke punoljetnosti odnosno sposobnosti, otkaza stranog državljanstva, teritorijalne veze s Hrvatskom te poznavanja hrvatskog jezika (čl. 12. ZD-a),

- hrvatski državljanin koji je ishodio otpust iz hrvatskog državljanstva (što mu je kao pretpostavku za obavljanje poziva ili djelatnosti postavila strana država u kojoj ima prebivalište), ako se iz njegovog ponašanja može zaključiti da poštuje pravni poredak i običaje u RH i da prihvaća hrvatsku kulturu (čl. 15. ZD-a),

- pripadnik hrvatskog naroda koji nema prebivalište u RH, ako se iz njegovog ponašanja može zaključiti da poštuje pravni poredak i običaje u RH i da prihvaća hrvatsku kulturu te ako dade pisanu izjavu da se smatra hrvatskim državljaninom (č. 16. st. 1. ZD-a). 
Pravilnika, mišljenje daje Vijeće Hrvatskog olimpijskog odbora, imajući u vidu sljedeće kriterije (čl. 7. Pravilnika):

- razvoj i rezultate odgovarajućeg sporta u Republici Hrvatskoj, te rezultate sportaša koji traži hrvatsko državljanstvo

- planirani razvoj nacionalne selekcije određenog sporta

- značaj i mogući utjecaj na stvaranje domaćeg podmlatka sportaša pojedinog sporta

- mogućnost unapređenja sportskih rezultata nacionalne selekcije na nacionalnoj i/ili međunarodnoj razini razini

- značaj sportaša i njegovih sportskih rezultata na promociju sporta na nacionalnoj

- ostale karakteristike kao i moguće efekte ili posljedice nastupa sportaša koji traži potporu za stjecanje hrvatskog državljanstva za odgovarajući klub odnosno nacionalnu selekciju.

Što se tiče propisa nacionalnih sportskih saveza, pravila Hrvatskog nogometnog saveza u pogledu državljanskog statusa igrača temelje se na odredbama sadržanima u statutima FIFA-e i UEFA-e, ${ }^{108}$ te u ondje navedenim ograničenjima.

Pravila Hrvatskog košarkaškog saveza također su usklađena s odredbama Međunarodnog košarkaškog saveza. Tako Pravilnik o državnim reprezentacijama iz 2000. godine ${ }^{109}$ izričito predviđa da za državne reprezentacije mogu nastupati državljani RH, sukladno propisima FIBA-e (čl. 14.).

Hrvatski rukometni savez pitanje državljanstva rukometaša uređuje u Registracijskom propisniku iz 2009. godine i u Propisniku o statusu rukometaša iz 2006. godine. ${ }^{110}$

Za razliku od Olimpijske povelje, statut Hrvatskog olimpijskog odbora ne sadrži posebne odredbe o državljanstvu sportaša.

\section{UMJESTO ZAKLJUČKA}

Iako se, prima faciae, nameće zaključak da je praksa trgovanja sportskim talentom izum novijeg doba i izravna posljedica globalizacije, ona je postojala još u vrijeme helenske republike, gdje su sportaši koji su se natjecali na grčkim Olimpijskim igrama često svoje talente prodavali državi koja plaća najviše. ${ }^{111}$ Mnogo je primjera i poslije kroz povijest. Tako je, primjerice, državna reprezentacija predratne

108 Vidi: Pravilnik o registraciji klubova i igrača HNS-a. Preuzeto sa www.hns-cff.hr/upl/.../ Pravilnik_o_registraciji_klubova_i_igrača.pdf, 15. XII. 2016.

109 Pravilnik HKS-a o državnim reprezentacijama. Preuzeto sa www.hks-cbf.hr/dokumenti/pravilnici, 15. XII. 2016.

110 Preuzeto sa www.hrs.hr/dokumenti.php, 12. XII. 2016.

111 Kozlowska, H./Traywick, K.A.: In the Olympics, the country you represent could be meaningless. Preuzeto sa http://www.news-herald.com/article/HR/20140206/NEWS/140209426, 14. XII. 2016. 
Njemačke, nakon pripojenja Austrije Njemačkoj (1938. - 1945.), apsorbirala najbolje austrijske igrače te Poljaka Ernsta Wilimowskog, jednog od igrača $s$ najvećim brojem golova u povijesti poljske državne reprezentacije. ${ }^{112}$ Italija je, u pripremi za Svjetski kup 1934., naturalizirala nekoliko izvrsnih američkih igrača, potomaka iseljenika (Orsi, Monti, Demaria i Giuaita), te osvojila naslov svjetskog prvaka. ${ }^{113} \mathrm{~S}$ protekom vremena takvih je slučajeva bilo sve više. ${ }^{114}$

Naturalizacija je danas općeprihvaćena pojava, proces putem kojega pojedinac stječe status izjednačen sa statusom ,domaćeg“ državljanina. Međutim, dok je za domaćeg državljanina državljanstvo besplatno dobro, za naturalizirane državljane ono je više poput članstva u klubu. To stoga što moraju ispuniti određene uvjete da bi uopće mogli steći državljanstvo naturalizacijom. Načini na koje pojedinci postaju državljani i načini na koje se prosuđuje tko je vrijedan postati državljaninom, u velikoj mjeri otkrivaju i ideale u pozadini državljanstva i članstva u određenoj zajednici. ${ }^{115}$

Dakle, je li postojeći koncept državljanstva adekvatan i u sportskom kontekstu i treba li intervenirati u odnos državljanstva i sporta?

Imigracija i državljanstvo ne vezuju se isključivo uz pravni status. Fundamentalni dio te priče jest i status u smislu značaja i časti, odnosno članstva u zajednici od društvenog značaja. ${ }^{16}$ Državljanstvo bi, stoga, trebalo predstavljati gotovo posvećenu vezu između pojedinca i države. ${ }^{117} \mathrm{~Pa}$ ipak, to je sve manje tako. Sve raširenije prihvaćanje dvojnog državljanstva jasno govori u prilog promijenjene prirode državljanstva. Čini se da je globalizacija ipak uzela danak jer od četiriju temeljnih doktrina međunarodnog sportskog prava (pristupačnost, fair play, olimpizam i komercijalizacija ${ }^{118}$ upravo ova posljednja uvjerljivo dominira. Broj uvezenih sportaša koji su uspostavili labave veze s novom domovinom (ili tzv. „nomadskih kozmopolita“) $)^{119}$ i egzistiraju kao neugodan podsjetnik da čak i u igrama koje uključuju retoriku nacionalnog ponosa oportunizam ne poznaje granice, svakodnevno raste. Koliko god argument ukidanja uvjeta državljanstva, s ciljem dokidanja nepravde prema sportašima koji, unatoč izvrsnim rezultatima, zbog jake konkurencije u svojoj državi ne mogu do reprezentacije i Olimpijskih igara, ima

112 Vidi: https://en.wikipedia.org/wiki/Ernst_Wilimowski, 14. XII. 2016.

113 Podnar, op. cit., str. 1.

114 Ibidem.

115 Blinder, S.: Naturalisation as a British Citizen: Concepts and Trends, The Migration Observatory at the University of Oxford, May 2012., str. 8.

116 Anderson, B./Gibney, M./Paoletti, E.: „Citizenship, Deportation and the Boundaries of Belonging“" Citizenship Studies 15, 2011., str. 547.-563.

117 Spiro, P.: „Citizenship and the Olympics“, Insight on Law and Society, Vol. 16, Issue 3, 2016.

118 Olatawura, O. O.: „Fundamental doctrines of international sport law“, The International Sports Law Journal, 1 July 2008.

119 Vidi: Morgan, W. J.: „Cosmopolitanism, Olympism, and Nationalism: A Critical Interpretation of Coubertin's Ideal of International Sporting Life“, Olympika: The International Journal of Olympic Studies 4, 1995., str. 19-92. 
određenu težinu - neetičnost i amoralnost strateškog stjecanja državljanstva te „odljev mišića“" iz zemalja u razvoju ${ }^{120}$ također ne treba zanemariti.

Sloboda kretanja radnika ostavlja i sportašima sasvim dovoljno manevarskog prostora za ostvarivanje njihovih ekonomskih interesa, a bez strateškog stjecanja državljanstva. Pored toga, potrebno je voditi računa i o domaćim sportašima koji su cijelu svoju karijeru naporno trenirali da bi zaslužili čast da predstavljaju državu čiji su državljani od rođenja. Mišljenja smo da ne bi trebalo jednu nepravdu ispravljati drugom.

Zadržavanjem uvjeta naturalizacije sportaša postiže se njihova lakša asimilacija ili integracija u društvo države domaćina. Umanjuje se učestalost strateškog stjecanja državljanstva, u smislu stvaranja formalne veze bez ikakva drugog sadržaja imanentnog državljanskom odnosu. Zadržavanjem uvjeta naturalizacije sportaša ojačava se i vjerovanje u duh državnog natjecanja na globalnoj razini, a također i osjećaj ponosa utemeljen na uspjesima sportaša kao predstavnika te društvene grupe. ${ }^{121}$ Smatramo da se istom logikom vodio i CJEU, kad je, $\mathrm{u}$ više navrata, sastav državne reprezentacije proglasio pitanjem od isključivo sportskog interesa. Stoga, postojeći pravni okvir smatramo adekvatnim.

\section{SOME CITIZENSHIP ISSUES AS A PHENOMENON IN INTERNATIONAL SPORTS LAW}

In group and individual sports, the process of easier naturalisation of athletes is gathering greater momentum. Given that athletes must hold citizenship of a particular country in order to represent that country at international competitions, many countries lean towards this practice and offer many special visas or an eased naturalisation procedure for ,promising “ athletes. It is the same situation for performing at Olympic Games. It most often concerns foreign athletes who are members of national sport teams of the countries of which they are citizens who are expected to perform for the national team of the country they come to as foreign athletes. And while some in this situation do not perceive it as being bad, others call for serious consideration of the , potential mobility of athletes on the expected relationship among loyalty, identity and citizenship“. Therefore, the author attempts in this paper to answer the following questions: To what extent does globalisation and transnationalisation of sport change our perception of citizenship and belongingness? Is the existing concept of citizenship also adequate in the sports context? Does one need to intervene in the relationship between citizenship and sport?

Key words: citizenship, sport, naturalisation, performing in the state team, discrimination

120 Vidi: Hardman, A. R./Iowerth, H.: Sport, Patriotism, and the Olympic Games, July, 2012., str. 268-269. Preuzeto sa https://www.reserachgate.net/publication/272713746, 19. X. 2016.

121 Kostakopoulou/Schrauwen, op. cit., str. 30-31. 